\title{
US IMPERIALISM IN LATIN AMERICA: THEN AND NOW, HERE AND THERE
}

\author{
Henry Veltmeyer*
}

\section{Resumen}

En este artículo examinamos las acciones llevadas a cabo, desde el ocaso de la Segunda Guerra Mundial hasta nuestros días, por Estados Unidos de América y sus aliados que derivaron en el dominio geopolítico y económico de este país. El argumento señala a las Instituciones del Bretton Woods (Banco Mundial, Fondo Monetario Internacional, Organización Mundial de Comercio), el sistema de las Naciones Unidas, las alianzas militares (por ejemplo, la OTAN) como elementos clave en la protección de los intereses imperialistas de Estados Unidos. La visión del «desarrollo» es contextualizada como oportunista y menos altruista, y consecuente con la preocupación de las potencias de occidente de que los nuevos países independientes fueran atraídos por el modelo Soviético. El desarrollo, en consecuencia, intentó colocar una «cara humana» al capitalismo, colocándolo como un sistema socioeconómico aceptable. Exploramos los acuerdos comerciales, la cooperación militar y las acciones políticas que han solidificado la dominación estadounidense en Latinoamérica.

Palabras clave: imperialismo, capitalismo, desarrollo, Estados Unidos, Latinoamérica.

* Profesor-investigador del Doctorado en Estudios del Desarrollo de la Universidad Autónoma de Zacatecas y Director de la Red de Estudios Críticos del Desarrollo. 


\section{Abstract}

This article examines the global political actions undertaken by the United States and its allies since the Second World War toward the establishment and fortification of US dominance in geopolitical/economic spheres. It views the Bretton Woods institutions (World Bank, IMF, GATT-WTO), the United Nations System and military alliances (exempli gratia, NATO) as key mechanisms for the protection of US imperial interests. The post-war preoccupation with «development» is viewed as less altruistic than opportunistic, with the Western powers concerned that newly-independent developing nations would otherwise be attracted to the Soviet sphere of influence. Development, therefore, would place a «human face» on capitalism, making it acceptable as a socioeconomic system. The author examines free trade deals, military cooperation and political actions undertaken by the US as it solidified its dominance of Latin American countries.

Keywords: imperialism, capitalism, development, United States, Latin America. 


\section{INTRODUCTION}

inding itself in the wake of a second world war as the domi-
nant economic power in the «free world» the US strove as-
siduously to consolidate this power at the level of foreign policy. Under prevailing conditions that included the potential threat posed by the USSR and the fallout from a spreading and unstoppable decolonization movement in the economically backward areas of the world, United States (US) policymakers decided on, and actively pursued, a foreign policy with three pillars. One of these pillars was a strategy of economic reconstruction of an economically devastated Europe and the capitalist development of the economies and societies on the periphery of the system. A second pillar of the post-war order was what would become known as the «Bretton woods system», composed of three institutions (a Bank of Economic Reconstruction and Development-the World Bank today; the International Monetary fund; and a General Agreement on Tariffs and Trade that would morph into the WTO 50 years on) and the mechanism of the US dollar, based on a fixed gold standard, as the currency of international trade. ${ }^{1}$ The third pillar was would become the United Nations-a system of international organizations designed to provide the necessary conditions of (capitalist) development and collective security, a system of multilateral conflict resolution. ${ }^{2}$

1. On this system see, in particular, Bienefeld (2011) and Bello (2011).

2. The preamble of the U.N. Charter, constructed in the immediate wake of World War II by the assembled representatives of fifty nations concerned with issues of collective security and development, began with «the concept of a "family of nations", a system of multilateral conflict resolution and a more equitable world order. The charter was conceived as a people's charter, expressing the «common aims» of humankind. One of its main objectives was to apply multilateral negotiation mechanisms for the promotion of economic and social advancement of all peoples. To this end, topics such as decolonization, disarmament, economic and social progress, world trade, debt and the environment, industry and labour, science and technology, finance and foreign exchange, gender and development, and more recently peacekeeping were placed on the agenda of diverse organizations within the UN system. 
The motivating force behind this foreign policy was clear enough: to advance the geopolitical and economic interests of the US as a world power, including considerations of profit and strategic security (to make the world save for US investments and to reactivate a capital accumulation process). It was to be an empire of free trade and capitalist development, plus democracy where possible, a system of capitalist democracies backed up by a system of international organizations dominated by the US, a military alliance (NATO) focused on Europe in the protection of US interests and collective security, and a more global network of military bases to provide logistical support for its global military apparatus.

Within the institutional framework of this system and international order the US was particularly concerned to consolidate its power and influence in Latin America and the Caribbean, regarded by policymakers and many politicians as a legitimate sphere of undue influence-the exercise of state power in the «national interest». This chapter will elaborate on the economic and political dynamics of the efforts pursued by the US to pursue these interests via the projection of state power-and the resulting «informal empire» constructed by default.

\section{US IMPERIALISM IN LATIN AMERICA-FORMS AND DYNAMICS}

The US has always been imperialistic in its approach to national development in Latin America, but in the wake of World War II the situation that it found itself in-commanding, it is estimated, half of the world's industrial capacity and $80 \%$ of its financial resources; and already an occupying power of major proportions ${ }^{3}$-awakened in US policymaking circles and its foreign policy establishment

3. US occupation of Germany and Japan was seen as temporary only and not as part of a colonisation policy. In this context, Germans and Japanese, and people elsewhere welcomed US bases, seeing them as part of their own defences; and in the same spirit they accepted the rule of the dollar and welcomed US investment and multinational corporations. Lundestad (1998) dubs the resulting system, presented as «Empire By Invitation». 
its historic mission regarding the Americas and also the dream of world domination, provoking the quest to bring it about in the preferred form of an «informal empire». A key strategy to this purpose was to institute the rules for what would later be termed «global governance»-for securing its economic and geopolitical strategic interests in a world liberated from colonial rule (id est competing empires). The resulting world order, dubbed Bretton Woods I by some, ${ }^{4}$ provided an institutional framework for advancing the geopolitical strategic interests of the US in the context of a «cold war» waged against the emerging power of the USSR, and for advancing cooperation for international development, a policy designed to ensure that the economically backward countries seeking to liberate themselves from the yoke of European colonialism would not succumb to the siren of communism, that they would undertake a nation-building and development process on a capitalist path. ${ }^{5}$

This development project required the US to assume the lead but also share power with its major allies, strategic partners in a common enterprise organised as the OECD and a united Europe, ${ }^{6}$ with a system of United Nations institutions to provide a multilateral response to any security threats (and that prevented any one country for embarking on the path of world domination via unilateral action. This was the price that the US had to pay for national security under conditions of an emerging threat presented by the

4. In the Bretton Woods negotiations the British were overruled, while the others were allowed almost no contribution. However, everyone was all too aware of the coercive element in the new international regime. But they accepted American hegemony as the price for economic growth and military protection from Soviet communism-leadership of the «free world» based on the virtuous marriage of democracy and capitalism.

5. The development project, announced in 1948 by President Truman, took the form of a Point-4 Program of international assistance and foreign aid to prevent other nations to follow a radical path of development.

6. Although it would take decades to bring about, a strong European economy and a united Europe were deemed by the US as essential to its strategic interests and containment of USSR power. As Mann (2007) points out, the US only required that «Europe not seek to become an independent third force and that European re-armament fit into the larger Atlantic framework, the code for American domination». Coversely, he added, the Europeans understood that they paid for their defence by subsidizing the dollar. 
USSR-soviet communism backed up by what was feared to be a growing if not commanding state power.

In this context the US began to construct its empire, and it did so on a foundation of six pillars:

1. Consolidation of the liberal capitalist world order, renovating it on neoliberal lines in the early 1980s when conditions allowed;

2. A system of military bases strategically across the world, to provide thereby the staging point and logistics for the projection of military power when needed, and rule by military force when circumstances would dictate;

3. A project of cooperation for international development, to provide financial and technical assistance to countries and regimes willing to sign on the project-to provide a safe haven for US economic interests and pave the way for the expansion of capitalism and democracy, the bulwarks of US imperialism;

4. Implementation of a neoliberal agenda of policy reforms-to adjust the macroeconomic and development policies to the requirements of a new world order in which the forces of freedom would be released from the constraints of the welfare-development state;

5. Regional integration-construction of regional free trade agreements to cooperate with, and not discriminate against, US economic interests regarding international trade;

6. Globalization-the integration of economies across the world into the global economy in a system designed to give maximum freedom to the operating units of the global empire.

Each strategy not only served as a pillar of imperial policy but provided the focal point for the projection of state power in different forms as circumstances required or permitted. Together they constituted what might be termed imperialism. Each element of the system was, and is, dynamic in its operations but ultimately unstable because of the countervailing forces that they generated. 
Rule by armed force: War in the informal empire

Within ruling class circles in the US since at least 2000 there is an open acceptance that theirs is an imperial state and that the US should maintain or act to restore its dominant position in the $21 \mathrm{st}$ century by any means available, and certainly by force if need be.

The whole tenor of the debate in the past two decades over US foreign policy, Mann (2007) notes, is framed in these terms. In this connection, Richard Hass, the current director of Policy Planning in the State Department, wrote an essay in November 2000 advocating that the US adopt an «imperial» foreign policy. He defined this as «a foreign policy that attempts to organise the world along certain principles affecting relations between states and conditions within them». This would not be achieved through colonization or colonies but thorough what he termed «informal control» based on a «good neighbour policy» backed up by military force if and when necessary-harking back to the «informal empire» of a previous era (McLean, 1995; Roorda, 1998). Mechanisms such as international financial markets and structural reforms in macroeconomic policy, and agencies such as the World Bank, the WTO and the IMF, would work to ensure the dominance of US interests, with the military iron fist backing up the invisible hand of the market and any failure in multilateral security arrangements. This system of «economic imperialism», maintained by US hegemony as leader of the «free world» (representing the virtues of capitalist democracy), was in place and fully functioning from the 1950s throughout the 1980s and the reign of Ronald Reagan. In the 1990s, with the disappearance of the threat of the Soviet Union and international communism, this system of economic imperialism, based as it was on the hegemony of «democracy and freedom» as well as multilateralism in international security arrangements, did not as much break down as it was eclipsed by the emergence of the «new imperialism» based on the unilateral projection of military force as a means of securing world domination in «the American century». ${ }^{7}$

7. The 1992 Wolfowitz Report asserted explicitly that the US had to maintain a mil- 
This conception of a «new imperialism», a «raw imperialism» that would not «hesitate to use [coercive] force if, when and where necessary» (Cooper, 2000), based on "aggressive multilateralism» or the unilateral projection, and strategic use, of state power including emphatic military force, was advanced in neoconservative circles over years of largely internal debate, and put into practice by a succession of regimes, both democratic and republican. It achieved its consummate form in George W. Bush's White House, in the Gang of Four (Donald Rumsfeld, Paul Wolfowitz, Condoleeza Rice, Dick Cheney), ${ }^{8}$ and its maximum expression in a policy of imperial war in the Middle east and the Gulf region. Although the US also projected its military power in other theatres of imperial war such as Yugoslavia ${ }^{9}$ and Colombia (viz. the covert Colombiacentred class war «on subversives» against the FARC-EP' and the overt regional "war on drugs») the policy of imperial war and the strategy of military force were primarily directed towards the Gulf region (see, inter alia, Petras and Veltmeyer, 2003).

In the academic world the issue as to the specific or dominant form taken by imperialism has not been generally framed as a matter of when and under what circumstances military force might be needed or legitimately used (generally seen as a «last resort» but as the necessary part of the arsenal of force available to the state, conceived of as the only legitimate repository of the use of violence in the «national interest»). Rather, the issue of armed force in the imperialist projection of military power has

itary machine so powerful as to discourage local or global rivalries. Under George W. Bush this doctrine was converted into policy.

8. During the Clinton years of the 1990s the neocons were active in conservative think tanks and projects such as the PNAC (the Project for a New American Century), which included plans for gaining control over the region's oil fields, and to attack Iraq and Afghanistan, long before 9/11. But they had to bide their time-until the elevation of George W. Bush to the presidency. With the added complement of Condoleeza Rice and Colin Powell, authors of the Defence Guidance Planning (DGP), a document that outlined the need for the US to assert its power unilaterally («when collective action cannot be orchestrated») in the service of global American Empire, the neocon noose around the neck of US foreign policy was set to be tightened.

9. On the dynamics of US imperialism in Yugloslavia see Morley (2010). 
been framed in terms of an understanding, or the argument. That an imperial order cannot be maintained by force and coercion; it requires "hegemony», which is to say, acquiescence by the subalterns of imperial power achieved by a widespread belief in the legitimacy of that power generated by an overarching myth or dominant ideology-the idea of freedom in the post world war II context of the "cold war» against communism and the idea of globalization in the new imperial order established in the 1980s. Power relations of domination and subordination, even when backed up by coercive or armed force, invariably give rise to resistance, and are only sustainable if and when they are legitimated by an effective ideology-ideas of «democracy» and «freedom» in the case of the American empire or "globalization» in the case of the economic imperialism that came into play in the 1990s.

It is no accident that the 1990s saw the advent of a newmilitary-form of imperialism. For one thing, the idea of globalization, used to legitimate and justify neoliberal policies of stabilisation and structural reform, had lost its commanding force-its hold over the minds of people, particularly among classes within the popular sector. As a result, the 1990s in Latin America saw the advent and workings of powerful forces of resistance to the neoliberal policy agenda and the machinations of US imperialism. To combat these forces of resistance state officials resorted to different strategies and tactics as dictated by circumstances, generally by combining development assistance and outright repression (on this see Petras and Veltmeyer, 2003).

How this worked in practice can be illustrated in the case of Paraguay in recent years. In 1996 the then government presided over by Nicanor Duarte decreed as legal the presence of military and paramilitary forces in the countryside because the police were unable to contain the peasant struggle. At the same time and in the same context the regime authorized the presence of American troops, giving them immunity for any violation of the country's laws that might occur in the process of their «humanitarian assistance» (counterinsurgency training) 
provided the Paraguayan troops. It was alleged by the peasant organizations that some of the nongovernmental organizations operating in the area and financed by USAID are also enlisted to provide assistance in controlling the population, diverting the rural poor away from the social movements; have them opt for local micro-development projects instead. In this sense, what is happening in Paraguay is in the time-honoured US tradition of combining the iron fist of armed force with the velvet glove of local development on the front lines of rural poverty.

Elsewhere in the global US empire, neither neoliberalism in policy or resistance in the form of social movements was as virulent as they were in Latin America. As a result, the idea of "globalization» had more currency in other macro-regions of the empire than it ever had in Latin America (Bowles and Veltmeyer, 2007). It would require the events of $9 / 11$, and the resurrection and reconstruction of the US's global mission (to defend the free world) the administrators of the empire under George W. Bush to escape the confines of «globalization» and dispense with its constraints, ${ }^{10}$ allowing the administration to institute the «new imperialism» with as much overt force and military power as the state could dispose of., multilaterally if possible but unilaterally if necessary ${ }^{11}$

10. The problem with any ideology is that it often works as a two-edged sword. On the one hand, it serves as an effective device for mobilising action towards a desired goal in the interest of a group or class with which the ideologue identifies. But on the other hand, like all ideas when acted upon, institutionalised in practice, it also constraining, limiting the form and force of the action taken.

11. Of course the declining force of the idea of globalisation, and the missionary zeal of and powerful belief of the neoconservative in its mission, were by no means the only factors in this transition to military imperialism. Its ability to construct a new «enemy»-《international terrorism») to replace «communism» was certainly a critical factor, as was the general decline in US economic and political power-the series of reverses in state power experienced by the US since Vietnam, which provoked in US officials and policy makers the need for a serious counter-offensive. Also, even before $9 / 11$, faced with its declining influence in strategic regions, a growing economic crises at home, the end of the speculative (IT, biotech, fibre-optic) bubble, Washington decided to begin militarizing its foreign policy (via Plan Columbia) and to aggressively pursue comparative advantages via unilateral state decisions: abrogating treaty agreements (ABM missile agreement with Russia, Kyoto Agreement, the International Human Rights Court, anti-biological warfare and anti-personnel/ mining agreements, etc.) Unilateral action was seen as a way of reversing the relative decline, combining regional military action and economic pressure. 


\section{International development}

Overseas Development Assistance (ODA) - foreign aid, in more common parlance-is widely viewed as a catalyst of economic development, a boost to «developing societies» economies to assist them in following the path towards progress and prosperity traced out by the club of rich or advanced capitalist countries. But is possible to look at foreign aid in a very different way-as a means of advancing the geopolitical and strategic interests of the governments and organizations that provide this aid. In 1971, at the height (but impending crisis) of the Bretton Woods world economic order, this view was expressed in the notion of «imperialism as aid» (Hayter, 1971). The purpose of aid was essentially geopolitical: to ensure that countries that the former colonies of British-led European imperialism upon achieving national independence would not fall prey to the lure of communism and to ensure that they would follow a capitalist path towards their national development.

In the wake of the Cuban Revolution the US redirected its «development» efforts and its entire strategy away from nationbuilding towards the countryside in various «developing societies» where there was a build-up of revolutionary ferment. In Latin America, where this new strategy was concentrated this entailed the construction of the «Alliance for Progress» a new policy and institutional framework of international cooperation for rural development, a project aimed at the rural poor-to turn them from the confrontational politics of the social movements and opt instead for local development (Veltmeyer, 2005).

In the 1960s and 1970s, a combination of this approach with a strategy of cooptation of the leadership of the social movements, and strategic use of its repressive apparatus, resulted in the defeat of the impulse towards social revolution among the rural poor and destruction of the armies for national liberation that had sprouted throughout the Latin American countryside under conditions of imperialist and class exploitation. The Revolutionary Armed Forces of Colombia-the People's Army (FARC-EP) 
was one of the very few such revolutionary organisations in the region that survived. The occasional fragile unity of the forces of resistance mounted by organised labour in the cities and the proletarianized peasants in the countryside was everywhere broken, and the remaining forcers of resistance were demobilised and went to ground, awaiting more favourable conditions. As it turned out such conditions only materialised in Chiapas, allowing the grounded forces of resistance to reappear under changed conditions-erupting, in this case, on January 1, 1994, the day in which NAFTA, a new offensive in the imperialist war, was launched.

This particular offensive, as it turned out, would also be ultimately defeated-not by armed force but by a policy of strategic isolation and encirclement. In other contexts-particularly in Brazil, Ecuador and Bolivia-the forces of resistance against neoliberalism and US imperialism were more successful. Indeed, the social movements in these countries succeeded in either halting, slowing down and even, in some cases, reversing the neoliberal agenda, placing state officials in these countries, as well as the agencies of US imperialism, on the defensive. It would take another decade of concerted actions against these movements to hold them at bay. Again it was not armed force but the project of international cooperation for «development», implemented within the new policy framework of the post-Washington consensus (PWC), that was primarily responsible for dampening the forces of revolutionary change in the region.

The political Left, having abandoned the revolutionary struggle, was complicit in this defeat of the social movements. Certain elements took up positions within the development project on the basis of what John Holloway (2002) views as a «no power» approach to social change (to bring about change without taking power). Other elements of the Left opted for what used to be termed the "parliamentary road» to state power, namely democratic elections. By 2005, with the notable exception of Bolivia, where the revolutionary forces were actively mobilised in the struggle to prevent the privatisation of the country's strategic natural resources, the wave of social 
movements that had washed over the neoliberal state in the 1990s had ebbed, weakened and forced into retreat by the very centreleft that had achieved state power in the wake of widespread disenchantment with neoliberalism (Petras and Veltmeyer, 2009, 2011).

\section{The neoliberal agenda}

The neoliberal agenda, a prominent feature of the economic imperialism of recent years, had been decades in the making ${ }^{12}$ but it was not till the early 1980s, in the vortex of two crises, that the conditions needed for its implementation became available. The fiscal crisis provided the political conditions of a conservative counterrevolution in development thinking and practice-for the advent of neoliberalism. On the other hand, the debt crisis, which provided a lever for adjusting government policies to the requirements of this new world order.

While the World bank and the IMF might be considered the operational units of the economic imperialism, its brain trust, as it were, was constituted by an array of neoconservative and neoliberal institutions, including the Pelerin Society, a neoliberal thought collective constituted to advance free market capitalism at the level of national policy (Mirowski and Plehwe, 2009). It also includes the Council on Foreign Relations, a complex of policy forums and Washington-based foundations. The institutional structure of this «new world order» encompasses the World Bank, the

12. Mirowski and Plehwe (2009) provide a systematic review of the relevant literature and an analysis of the origins and itinerary of neoliberalism as an ideology, economic policy doctrine and political philosophy. As they see it, neoliberalism so defined can be traced most effectively to the workings of the Mont Pelerin Society (MPS), an organisation of over 1000 like-minded intellectuals-economists, philosophers, sociologists that share the belief in the need to promote free market capitalism and a strong state able to bring it about. Members of the MPS includes Milton Friedman, an architect and avid supporter of the economic policy program implemented by Augusto Pinochet in Chile; Alfred Schultz, the sole dissenting voice in the 1950s and 1960s consensus among development scholars and practitioners on the need for a welfare-development state; and Pat Buchanan, a prominent member of the neoconservative intellectual and political establishment. 
IMF and the WTO, the latter stillborn in 1944 negotiations, not constructed until 1994 in a major shift in imperial strategy manifest in and coinciding with the institution of NAFTA.

The impetus behind the call for a «new world order» in the 1980s was to resolve the fiscal and production crisis, to advance capitalist development on a global scale, and create a policy agenda for advancing these interests, which are represented most directly in the operational units of this system, namely the multinational corporations which could be defined as the crack troops of US economic imperialism. The dynamics of these institutions viz. globalization and structural adjustment, and the role in the design and implementation of macroeconomic policy, are well documented, much more so than the operations of the CFR and even more so of the MPS, whose members have played a major role in the promotion of neoliberalism, to finance research centres and policy forums to promote $a$ ) free enterprise and the free market; $b$ ) economic integration in the form of regional free trade agreements; $c$ ) macroeconomic policy in the form of structural reform.

This project, based on a neoliberal agenda, can be traced back to the 1940s, to ideas promulgated at the time by members of the Pelerin Society, but was only seriously advanced in the 1980s when political conditions for a counterrevolution in development theory and practice-a new world order-were favourable. ${ }^{13}$

In the mid-1980s the neoliberal agenda for «structural reform» was advanced in the form of globalization, the ideology constructed as a means of mobilising support for this policy agenda, presenting it as a consensus and a development program, the only way forwards to general prosperity-and to establish hegemony over the whole system (World Bank, 1995). By the end of the decade,

13. The call for a «new world order» was made under the presidencies of Ronald Reagan and George W. Bush by neoliberal ideologues and policy advisers working at diverse right-wing (neoconservative) Washington-based foundations and policy forums. One of the most powerful and influential policy forums was provided by the Heritage Foundation, which led the ideological fight to install the «new world order» and the «new economic model» to guide macroeconomic and development policy. 
however, the idea of globalization fractured and succumbed to forces of resistance. It no longer served as an effective ideology to justify and mask the neoliberal policy agenda, leading to a major revision in the agenda, an effort to provide it for a human face-present its as the policy framework for as more inclusive form of national and local development, designed to empower the poor, capacitating them. By the new millennium, this PWC was achieved in the form of a more pragmatic form of neoliberalism pursued by the centre-left regimes in the region that had assumed and remain in power.

\section{Regionalism}

The first projection of an imperial strategy of regional free trade arrangements was in the immediate post-war period in which the US was constrained in its own national interest to push for the integration of Europe-the creation of a strong economy and a system of cross-Atlantic state alliances that would provide an important market for the US as well as a bulwark against communism and the growing power of the USSR.

Subsequently, the decade saw an important twist if not turn in imperial policy defeated by the forces of resistance in the region. The impetus behind this strategy, certainly in the case of Latin America was to reverse the large and growing trade deficit with countries in every region except, as it happens, in Latin America. In fact, Latin America was a crucial factor in offsetting a growing deficit on its global trade account, and NAFTA (and later FTAA) were viewed, and used, as a mechanism of economic imperialism.

The now defunct Latin America Free Trade Agreement (LAFTA) was a key element of Washington's empire-building project in Latin America-an extension of NAFTA, (Cafta-DR) and its bilateral agreements with Chile, Colombia and Peru. The FTA if it had succeeded, would have given US MNCs and banks unrestrained access to markets in the region, as well as raw materials and labour, while limiting European and Japanese entry and protecting US markets. This neomercantilist imperialist device was another 
unilateral initiative, taken in agreement with the client states such as Colombia and Peru in the region without any popular consultation. Given the high levels of discontent already in the region, under the neoliberal regimes, the imposition of neomercantilist imperialism would likely have led to explosive social conditions and the re-emergence of nationalist and socialist alternatives. As it is the alternative trade agreement advocated by Hugo Chávez, ALBA, has provided a major counterpoint and countervailing force to US imperialism in the region.

\section{THE DYNAMICS OF EMPIRE-BUILDING IN LATIN AMERICA}

The informal US Empire, constructed in the post-war years, extended into and held sway in five macro-regions. The dynamics of these forces and the working of imperialism in each region is substantively different. But in this chapter we are only concerned with Latin America, where the US Empire was extended from its original base in Central America and Mexico to points further south to encompass virtually the entire region.

The workings of empire in the region can be traced out in three

phases that more or less correspond to empire-building efforts elsewhere.

\section{5-79 US imperialism in an era of state-led capitalist development}

In the American hemisphere after the second world war the informal US empire remained largely unchanged, although it began to creep further southward. The region was seen as having relatively low strategic and economic value, and received less economic or military attention from the US than other regions. The bigger states in the hemisphere pursued their own development path while the US was content to influence the smaller states in its backyard through comprador regimes that shared US preference for authoritarian regimes and conservative forms of capitalism. 
However, these regimes more often than not were confronted by populist force of resistance, by workers in the cities and peasants in the countryside, demanding and actively mobilising for social change. If and when these forces achieved power as they did in Cuba in 1959, they drove a hard bargain with American corporations and financial interests as well as the ruling classesthreatening US «interests», leading US officials to brand them as "communists», enemies of the forces of freedom and democracy. Alternatively, where local class conflict intensified, the US perceived a danger of escalation to «chaos» and then perhaps to «communism». Both outcomes were perceived to threaten US interests. In response, or in some conjunctures in anticipation of this threat, the US mobilised its military assets in attempting to overthrow regimes deemed to be antithetical to its «interests»-Arbenz in Guatemala (1954), Fidel Castro in Cuba (1961), Bosch in the Dominican republic (1963), Goulart, a moderate nationalist, in Brazil (1964), the Dominican Republic (1965), Jagan in Guyana (1953) and then Allende in Chile (1973). ${ }^{14}$

Arbenz was deposed by military force in a direct military invasion but the dismal failure of this tactic in Cuba (viz. the Bay of Pigs debacle) led the US to elaborate and pursue an alternative strategy of sponsoring military coups and a concerted regional strategy of a «dirty war» by proxy against subversives, using the armed forces of the countries in question, arming them and training them within the framework of a National Security Doctrine (NSD) constructed to the purpose. In 1964 this strategy was successful in removing Goulart from power in Brazil because of his nationalist threat to US interests-to nationalise US assets and property. Within one hour of his removal from power by the US-

14. It might be remembered that the US interventionist success in Guatemala (1954) caused the US to repeat its policy with Cuba in 1961-a policy that led to defeat. The successful US orchestrated military coups in Brazil (1964) and Indonesia (1965) and the invasion of the Dominican Republic (1965) encouraged the US to deepen and extend its military invasion of Indo-China which led to a historic but temporary defeat of imperial policymakers and the profound weakening of domestic political support. 
trained Armed Forces the new self-proclaimed President of the country, was congratulated by President Johnson for «restoring democracy» to Brazil. A decade later, Salvador Allende, also democratically elected but unlike Goulart a proclaimed "socialist", was removed from power by means of a violent coup engineered and financed by the US, allowing the subsequent military dictator $\mathrm{Au}$ gusto Pinochet to implement a neoliberal agenda at the level of national policy-as well as «teach the world a lesson in democracy». Other NSD-based military coups, all supported by the US, took place in Bolivia (1911), Uruguay (1972) and Argentina (1976).

In this period, the US launched several open military interventions but far more covert or proxy ones. It was an informal empire, mixing gunboats with proxies but without colonies. It was generallyjustified or legitimated as the spread of freedom and democracy, with communism presented as the antithesis of democracy, the enemy of freedom. But this mission statement was undercut by the clear US preference for authoritarian allies and the sponsoring as well as support an propping up of military dictatorships in the region.

In reviewing the dynamics of US imperialism in this period there was essentially two major strategies pursued, each with appropriate tactics. The two-pronged strategy included use of the «iron fist» of military force within the velvet glove of development assistance or foreign aid. The resort to military force has already been alluded to in the sponsoring or support of military coups across the region from 1964 to 1976 . However, and equally important use of imperial power took the form of rural development-NGO-mediated assistance to the rural poor to prevent them from joining or forming social movements pressing for revolutionary change. ${ }^{15}$

The state was assisted in this struggle but in the wake of the Cuban revolution the US redoubled its efforts on the ground, using

15. On NGOs as agents of US imperialism see Petras and Veltmeyer (2001) and Veltmeyer (2009). 
community development activists and organizations to penetrate the countryside and turn the rural poor away from social revolution, to teach them the virtues of democracy, capitalism and reform. By these means, and a deployment of nongovernmental organisations on the frontline of the war on rural poverty, the agents of the state managed to dampen the revolutionary ferment in the Latin American countryside. Where this effort did not suffice in demobilising the forces of revolutionary change the state stepped in with its repressive apparatus. By the end of the 1970s virtually every army of national liberation had been destroyed or decapitated-FARC in Colombia a notable exception. In many cases as in Mexico in Guerrero and Chiapas the revolutionary movement went to ground, held at bay or, as in the case of Chiapas, given time and space to rebuild, awaiting more favourable conditions.

\section{0-1990 Imperialism under the Washington Consensus}

By 1980 , the countryside was more or less pacified and labour was very much on the defensive in along class war waged against it by capital and the state, its leadership coopted, its forces in disarray and its ties to the peasant movement for land disarticulated, and its capacity to organise and negotiate with capital reduced. At the macro-level virtually very government has to contend with the conditions of a decade-long production crisis and an emerging fiscal crisis, as well as pressures to restore democracy, not in the authoritarian bureaucratic or military form pushed by the US but as the rule of law and civilian elected administrations responsive to demands from «the people», not a preserve of the political elite. As for the fiscal crisis, and the detritus of the 1970s production crisis in the form of stagnant production and runaway inflation, in the early 1980s it combined with conditions derived from US high interest rate policy and an unfavourable turn in the export markets to produce a scissor-squeeze on fiscal resource to precipitate a decade-long debt crisis and create conditions for launching the new world order. 
Unfortunately for the revolutionaries in Nicaragua these conditions also coincided with their capture of state power, provoking the contra affair, as the US government struggled, and used its proxies to launch covert military operations against the revolutionary regime. As it turned out this would be the last military adventure of US imperialism, its agents resorting instead to structural reform of macroeconomic policy (to create conditions for a renewal of foreign investment and reactivation of an accumulation process), international cooperation for local development (to demobilise or turn the rural poor away from the social movements), and co-opting «civil society» organisations in the responsibility of restoring order- «good governance» in the lingo of the new imperialism.

The emergence of neoconservative regimes in the US, the UK and elsewhere in the North, formed under conditions of a fiscal crisis, facilitated the implementation of the neoliberal agenda under the Washington Consensus on correct policy. Under these conditions US imperialism turned away from the generals, allowing them to be shunted back to the military barracks, and turned away from armed force towards the officials of the IMF and the World Bank, essential adjuncts of US state imperial, to help make Latin America safe for US capital.

It would take close to a decade for this to happen. But developments in the 1990s tell the tale: the privatization of key economic sectors and lucrative state enterprises (Petras and Veltmeyer, 2004); a major influx and reflux of capital, netting the empire, it is estimated (Saxe-Fernandez, 2002), over 100 million dollars in profit ${ }^{16}$ over a decade of neoliberal policies.

The «contras affair» closes one chapter in US imperialism and the installation of a new world order (id est implementation of

16. Profit in the sense of surplus value on invested capital-interest payments on loans; dividends paid out and profits repatriate profits on sales; royalties on «transferred» technology. See Petras and Veltmeyer (2004) on the different ways that this «cat can be skinned»-that potential surplus value or «financial resources» can be out-transferred. And this «international resource transfer» or flow of capital does not include the large pool of capital syphoned out of the economy via trade or labour export (Cypher and Delgado Wise, 2007). 
a «new economic model»-neoliberal globalization) opens another - a chapter characterised not by armed force, projection of military power, but rather what we might term «economic imperialism»-the engineering of free market «structural reforms' in national policy, the penetration of foreign capital in the form of MNCs (the shock troops of the old imperialism) and a free trade regime implemented in diverse regional contexts. The agents of this economic imperialism included the IMF and the World Bank and the WTO-the «unholy trinity» (Peet, 2003) - as well as the host of neoconservatives, neoliberal economists and policy makers that serve the «global ruling class» as described by Pilger (2000).

The new imperial order of neoliberal globalization was made possible, and facilitated, not only by a political turn towards neoconservatism but by new reserves of ideological power: the idea of globalization, presented as the only road to "general prosperity», the necessary condition for reactivating a growth and capital accumulation process. The idea of globalisation, used to justify and advance the neoliberal agenda, as noted above, came to replace the widespread call for a new world order, was launched in mid-decade. The World Bank's 1995 World Development Report, Workers in an Integrating World, could be seen as one of its most important programmatic statements, a capitalist manifesto on the need to adjust to the requirements of a new world order in which the forces of freedom would hold sway over the global economy.

The call for a new world order was led by Heritage Foundation and other Washington-based foundations and policy forums that, together with the US Treasury and Wall Street exemplified what became known as the "Washington Consensus» (although it also represented the wisdom of the City in London and finance capital everywhere). These Banks and international financial institutions would bail out the indebted countries, agreeing to «restructure» their loans in return for deep economic reforms-an austerity program of cutting central and local government spending, imposing high interest rates, stabilizing the currency, privatizing stateowned enterprises, abolishing tariffs, freeing labour markets from 
union restrictions, and opening up local capital markets and business ownership to foreign business. This was backed by a rhetorical neoliberalism declaring that morality and efficiency alike required reducing the power of governments, communal land ownership and labour unions. The freedom of markets and private property rights must rule.

As for the political adjustment to the «new world order» the US was constrained by its own declared mission to spread democracy and make the world safe for freedom, to support the widespread movement in diverse regions towards political democracy. As for Latin America, the US adapted to the spread of democracy across the hemisphere, conducting a policy of «democracy by applause» from the sidelines, as Latin Americans made their own democratic gains (Carrothers, 1991) in a process of redemocratization based on the negotiated pacted retreat of the generals to their barracks.

The structural adjustment program as implemented in the 1980s were unpopular to say the least, with the core opposition coming from organized labour and those dependent on the state. In some contexts democratic governments were reluctant to sign up and most programs were introduced by authoritarian regimes, as they were in Latin America in the 19790s, which made the IMF appear to favour dictatorships over democracies, just as the US did politically and militarily in this period (Berserker, 1992: 1146; Vreeland, 2003; 90-102). However, in Latin America, the SAP, representing a second round of neoliberal reforms, were generally implemented by civilian regimes or democratic governments that cam to power after the first experiments in neoliberalism crashed and burned in the early 1980s.

In the academic circles of the US empire there was a similar «adaptation» to reality, and to the ideology of free market democracy, in a reversal of the hitherto prevailing belief among political scientists in the liberal tradition that political authoritarianism provides a better fit and conditions for economic liberalism and development than democracy. In short order in the 1980s this idea gave way to the idea that economic liberalisation would lead 
to political liberalisation or vice versa, and that both were conditions of «development».

The 1980s paved the way for what could be regarded as the golden age of US imperialism in Latin America: a decade of pillage facilitated by a program of Washington-mandated structural reforms in national policy. Under these conditions in the 1980s all but four major governments in the region (especially Bolivia, Chile, Mexico, Jamaica) followed the WC or succumbed to direct pressures exerted by the IMF and the World Bank and structurally adjusted their economies. In the following decade, three of the major holdout countries in this «development»-Argentina, Brazil, Peru-made the belated transition towards neoliberalism. In Venezuela the memory of caracazo, a violently repressed wave of riots and protests in Caracas in 1989, was enough to hold back if not derail the neoliberal agenda of the governments of the day. It also helped created the political conditions that took form in the presidency of Hugo Chávez as the Bolivarian Revolution.

\section{0-1999 US imperialism and the post-Washington consensus}

The 1990s can be viewed as a decade of major gains for the social movements in their resistance to the neoliberal agenda of governments in the region and the operations and machinations of US imperialism. Already in the 1980s the push towards neoliberal policies had generated widespread opposition and protest, which in the case of Venezuela had resulted in a major social and political crisis - the Caracazo of 1989, in which hundreds of protesters against the high price of food and IMF policies were massacred by the state. More generally, conditions of structural adjustment across the region generated widespread opposition and resistance in the form of protest movements. They also led to a reorganisation and mobilisation of the forces of resistance in the popular sector. By the 1990s these organisations took form as antisystemic social movements formed on the social base of indigenous communities, landless workers and peasants. 
The rural social movements represented the most dynamic forces of resistance to the policies of neoliberal globalization and US imperialism. In a number of cases these movements managed to halt and even reverse the policies implemented under the neoliberal agenda. In the context it is even possible to name the decade as a decade of major gains for the movements.

However, the neoliberalism at issue in this resistance was not the same as it was in the 1980s, modified as it was by the search for a more socially inclusive form of development. ${ }^{17}$ The solution was a more socially inclusive form of neoliberalism-to give the structural adjustment process a human face-a new development paradigm and social policy targeted at the poor, empowering and capacitating them to act on their own behalf, in taking advantage of their «opportunities» for self-advancement (Sandbrook, Edelman, Heller \& Teichman 2007; World Bank, 2007).

In this context, the 1990s saw a major shift in the correlation of class forces, mobilised in support or against capitalist development in its neoliberal form. On the left, the political class was on the defensive, unable to make gains under condition of a divided and demobilised working class, and few ties to the new forces of resistance. The Left materialised basically in the form of social movements and, to some extent, social organizations for local development mobilised against the neoliberal regimes that were loath to accept the PWC and against new imperialist offensives such as NAFTAand beyond Latin America the 1994 Agreement on Trade-Related Aspects of Intellectual Property Rights (TRIPS). ${ }^{18}$

17. On the Post-Washington Consensus on the need to «bring the state back in» and a more inclusive form of participatory development, see Ocampo (2006, 2007), Sunkel and Infante (2010) and Petras and Veltmeyer (2011).

18. As Mann (2004) notes TRIPS had largely resulted from corporate lobbying. Sell (2002: 171-2) in this connection is quoted by Mann to state says TRIPS was «a significant instance of global rule-making by a small handful of well-connected corporate players and their governments». The chief executives of «powerful American-based rnultinational companies» with «superb access to the top levels of policy-making both at domestic and multilateral levels», he argues, became the founding members of an «Intellectual Property Committee» which lobbied for TRIPS within GATT, the negotiating forum for free trade that preceded the WTO. TRIPS was a triumph for the 
Most Latin American regimes at the time (the mid-1990s) were still aligned with the US. But the US, seeking to reverse major setbacks in Asia and other parts of the world, was rapidly losing influence and the capacity to dictate policy in the region or to counter the growing power of the social movements. The major exception here was Colombia, where the US continued with a major military presence. The governments of Mexico and Peru, and El Salvador in Central America, were (and are) also similarly aligned with the US.

\section{0-10 US imperialism under the Davos Consensus}

The first decade of the new millennium opened and is closing with an involution in capitalist production, a region-wide crisis in the first case, and a crisis of more global proportions in the second. The years betwixt and between, some six years under the presidency of George W. Bush and a shift in the political tide towards the centre-left in South America, the region actively participated in a primary commodities boom on the world market, a development that for some six years changed and to some extent reversed a historic pattern in the terms of north-south trade, bringing with it windfall profits for the private sector in agro-export production and unanticipated windfall gains in fiscal revenues for the centre-left regimes that had formed in the wake of a spreading disenchantment and turning away from neoliberalism. Unfortunately for the Left and the popular sector organisations that had pinned their hopes on these regimes the opportunity to change the course of national development in a popular or populist direction was missed; apart from Chávez's Venezuela no change in national policy could be discerned.

Quad states and their big corporations, working in concert, but they had exceeded their power. As Mann notes, when most of the 120 countries who had signed up to TRIPS realized the consequences they revolted. Resentment over this and other issues boiled over at the Seattle Ministerial Meetings in 1999, and they broke up in disarray, not without pressure from the antiglobalization movement, whose leaders took or were given credit for the failed corporate strategy. 
It would take the onset of crisis in October 2008 to bring about a change in fiscal policy and then not in the interest of a more equitable distribution of the social product but as part of a countercyclical strategy to boost demand. Throughout the decade what prevailed was a development policy program designed as a means of saving capitalism from itself-from a propensity towards crisis and from widespread forces of resistance held in abeyance by the centre-left in power. In addition to this post-Washington Consensus on development policy, which was implemented to different degrees by virtually every government in the region, what prevailed-and still prevails-is what the Economist (January 22, 2011: 13) describes as the «Davos Consensus»: the belief in the need to boost economic growth with free market capitalism (pro-growth policies of «structural reform»-privatization, deregulation, liberalisation), and to reduce the incidence of extreme poverty, via a strategy of enhancing human capital and targeted social expenditures. ${ }^{19}$

As for US-Latin American relations the Obama regime in the US has attempted to reconstruct them in an effort to reverse the decline in US power and influence over the past decade, a decline facilitated by the overriding concern of the George W. Bush Jr. administration with developments elsewhere in the empire. In the context of what might well be described as a «new military empire» based on «aggressive unilateralism» or unilateral action, ${ }^{20}$

19. In the service of this consensus the economists at the World Bank and the IMF in 1999 designed the Poverty Reduction Strategy Paper (PRSP) policy as a tool for achieving this policy objective. On the dynamics of this and other policy tools in the arsenal of the war on global poverty see Veltmeyer (2012).

20. Generally speaking, in terms of its global reach the US-led Empire entered a new and radically different phase in 1990, with the ascent to state power of George W. Bush. But this was not the case in Latin America. As for the shift from economic to military imperialism, Jim Mann (2004: 222-3, 371-2) writes, «reflecting on what they saw as a 35-year rise in American military capabilities'as America's principal tool in dealing with the world, the neo-cons that had come to power with George W. Bush formulated the strategy of unilateral action and preemptive strikes in terms of a greatly enlarged military capable of carrying a mission of freedom and forestalling strategic threats all around the globe. On this issue as well as silence on economic issues see Kagan and Kristol (2000) as well as Bacevich 
officials of the US imperial state in the 1990s was forced to turn its attention to greater priorities in other macro-regions-East Asia and even Europe (Kosovo), but especially the Middle East and gulf region. Except for a military invasion of panama in December 1989, which could be used to date its beginnings-and earlier skirmish in Grenada launched by Reagan in 1983 against the small island state in the Caribbean-the new military imperialism was almost entirely engaged elsewhere in the world, providing governments, parties and movements in the region space and time to conduct their affairs wit relatively little concern or interference from the US. ${ }^{21}$

\section{US IMPERIALISM IN LATIN AMERICA TODAY: PERU AND HONDURAS}

One of the ironies of the often commented on but generally misunderstood pattern of regime change -id est a supposed red or pink tide in national politics-over the course of the past decade

(2002), Daalder, Lindsay (2003), Mann (2004) and Packer (2005).

21. An exception to this proposition can be found in the US's war on drugs, particularly the operations of this war in Colombia. In fact, it has even been argued that in this context US military presence if not power has increased (Lobe, 1999). In a week that saw the official end of the US military presence in Panama in terms of bases and the southern command, the Pentagon's activities throughout Latin America, he argued, remained on the rise. According to a report released that week and summarised by Lobe, even as the last US military bases were handed over to the Panamanian government, Washington was actively establishing new military capabilities, called «Forward Operating Locations» (FOLs) on bases in Puerto Rico, Ecuador, Honduras, the Dutch Antilles, and possibly even Costa Rica-all in pursue oft the «war against drugs». In fact, Adam Isacson, co-author of the report (Just the Facts: A Civilian's Guide to US Defense and Security Assistance to Latin America and the Caribbean) stated that «the handover of the Canal Zone doesn't signal any shift in US military priorities and presence in Latin America». «It's not ending; it's just moving around», he added. In this connection, he noted that in 1998 nearly 50,000 US troops were deployed in the region, mostly for ant-drug as well as counter-insurgency training rather than military operations. In the context of the State department's continued anti-drug war operations since and now both in Colombia and elsewhere it is likely that US military «aid» and sales, as well as military training both at home and in the region (of «some of the region's worst human rights abusers», according to a recent House-Senate Conference Committee) have continued to increase (END/IPS/ jl/mk/99; Lobe, 1999). 
has been a weakening of the forces of resistance against neoliberalism, a retreat of the social movements in a context of revived dynamism of the Right-a weakening of the left and the strengthening of the Right. In part this is the result of misplaced views of the left that these regimes are «on their side»-anti-neoliberal in economic policy and anti-imperialist in their relations with the US. However, this is clearly not the case. Except for Venezuela, and of course Cuba, and to some extent Bolivia and Ecuador, these regimes or not in the least or only formally "populist» and can best be characterised as pragmatic neoliberal. In some cases, particularly in the case of Peru, Colombia and Mexico, the current and recent regimes can even be described as dogmatically neoliberal-not even as in the case of Chile, Argentina and Brazil, concerned with adapting neoliberal agenda to the post-Washington consensus on the need for a more inclusive form of neoliberalism.

A clear example of this is Peru, where the efforts of the government to protect the economic interests of US capitalism in June 2009 resulted in a major confrontation with the indigenous communities adversely affected by these interests, leading the government to resort to its repressive apparatus, resulting in the deaths of 24 police and 10 indigenous. Today, at the time of this writing (July 2009), the day after Alan Garcia announced a new cabinet in response to the growing wave of social and class conflict, and a month into the wave of conflict arising from the confrontation with the indigenous communities, thousands of workers have taken to the streets to demand a change in the government's neoliberal policies in the interest of US imperialism. At a time in which the Defensoría del Pueblo has identified up to 226 «active» social conflicts in the country, transport and public sector workers are on strike, joining in the march organised by the General Confederation of Workers (CGTP), the major Workers' Central in the country. At the same time on the periphery of Lima numerous streets blockades were reported, harking back or pointing towards the quasi-revolutionary situation or insurrection that emerged in Ecuador in 2000 and in Bolivia at various points between 2000 and 2005 (Webber, 2009). 
Similar situations are brewing in other countries in the region. But none of these are as meaningful for US imperialism as the current situation in Honduras brought about by the actions of the ruling class against the sitting and democratically elected President of the country. For US imperialism, Honduras represents not so much a political crisis, a crisis in US-Latin American relations, as a crossroads in imperial power and policy-in the way the US administration under President Obama to recover its position and influence in Latin America.

Today US imperialism in the region is at another crossroads. Whereas the primary commodities boom of 2002-08, at a time in witch the US administration was seriously distracted by the greater game in Eurasia and security concerns in the Gulf region, and too overstretched to attend to its Latin American affairs, 2008 saw the emergence of a somewhat if entirely new context for USLatin American relations.

It is in this context that Honduras took centre-stage for a time, eclipsing efforts of the regime to repair its relations with former client states and re-assert its influence if not dominance. The successful coup engineered in Honduras, and actively supported and even encouraged by the US administration, followed various similar interventions over the past decade-in Venezuela (unsuccessful) and Haiti (successful). In Bolivia, US intervention in Latin American affairs, in an effort to reassert its waning influence and declining power, took a different albeit not unconventional form: the financing of NGOs and active support of oppositional forces with the explicit subversive aim of destabilizing the regime. In this context US foreign policy in the region, aimed at reasserting its dominance, was focused on Colombia, its chief ally in the region and central to its empire-rebuilding project. The significance of Honduras in this context is that it represented an opportunity for the US to counter the growing influence of Hugo Chávez and his Bolivarian Revolution project in the region, particularly in its Central American domain, where Nicaragua and even El Salvador, not to mention Honduras, were vulnerable and at risk of being lost. In 
this context, Chávez, more than Raúl Castro, is perceived by the US to be the major obstacle in its efforts to restore its dominion, and this in part because of the financial resources Chávez is able to command but also because of the ideological attraction of his policies-particularly his project of 21st century socialism-in some circles, particularly among the popular classes.

In 1992, within hours of being deposed from power in a coup engineered by elements of Venezuela's ruling class, the US administration recognised the de facto regime. But it was soon forced to backtrack from this support when masses of poor urban workers rallied to Chávez's defence and forced his return to power. However, in the case of Honduras, given the immediate and definitive response of the OAS and its demand that Zayala be restored to office, the US had no choice in public to join the demand for Zalaya's return. Needless to say, the coup succeeded with the active, albeit covert, support of the US administration. Neither Honduras' ruling class, in control of the military apparatus as well as the legislature and the judiciary if not the government, nor the US administration had any intention to allow Zayala to track Chavez's path towards some new form of socialism. The US had any intention to allow this if it could be helped, and it is safe to assume that the State Department will stick at nothing in its efforts to prevent another Chávez. Democracy and capitalism have to be defended at all cost, regardless of any sensibilities regarding sovereignty, human rights or the freedom of a country to pursue its own development path.

\section{CONCLUSION}

Apart from Honduras, which provided the US both a challenge and an opportunity to recover lost political space, other issues on the agenda of the Obama administration include Cuba and how to counter the leftist tilt in national politics and an incipient but growing nationalism vis-à-vis control over natural resources and trade. 
Since 2001 a growing number of countries in the region have taken and are taking positions on policy and trade issues (the search to diversify trade relations, join ALBA) that are not in the US national interest, and Obama has undoubtedly been briefed as to how to respond to this challenge to US power and influence. Of particular concern for US imperialism is the movement of more and more countries in its immediate backyard and former sphere of influence, the Caribbean and Central America, towards and into the Chávez orbit (Petrocsaribe, etc.). In this panorama, Honduras too provides favourable conditions for a Washington-made solutiona US military base, intimate regular day-to-day relations with Armed Forces personnel, a malleable and supportive Congress and Supreme Court, a ruling class that shares its concerns about the actual and possible forces of subversion in the country and region.

In some ways the situation confronted by Obama in Central America is similar to that faced by President Reagan in the early 1980s regarding Nicaragua? But Reagan had on his side a number of cronies and dictators-Alvarez in Uruguay, Videla in Argentina, Pinochet in Chile, Stroessner in Paraguay. In this regard at least the political landscape in Latin America has indeed changed. The majority of countries in the region might be described as centrist and pragmatic in terms of macroeconomic policy, rather than leftist (national populist) or rightist (neoliberal), but are also concerned to maintain a line of independence vis-à-vis the US on matters of foreign relations and policies. What this means for the current Obama administration might be gauged by its reaction to the nomination of Insulza, a social democrat close to, and a nominee of, Chile's Bachelet, for the position of OAS Director. It seemed that the US was implacably opposed to his nomination, apparently (according to several Washington «insiders») because of Inzulza's support for Cuba's entry into the OAS, his campaign against the «golpistas» in Honduras and his earlier denunciation of US intervention in Venezuela. If this be the attitude and position of the US vis-à-vis a noted progressive and liberal social democrat, a representative of a centrist and pragmatic position in Latin American politics and the nominee of 
a country supportive of the US and allied with it at the level of bilateral trade, what might the position of the Obama administration be regarding relations with regimes seeking to strike a more independent a line and steer a leftward course? Obama's administration at the outset made various overtures to governments in the region such as Lula's in Brazil with which previous US administrations had strained relations, but how the Obama administration copes with an emergent push in the region for greater indepndence, and how it relates to Chavez and to the right-wing opposition in countries such as Honduras, Bolivia and Venezuela, and how it dealt with the «Honduras question») provided a clear sign of the direction that US imperialism is taking in the region. If the Obama regime's current mix of strategies and tactics fails to bear fruit, and if politics in the region tilt or turn further to the right as it appears to be doing (witness developments in Chile), then the US might well return to its historic policy of direct intervention in Latin American affairs and support for military coups-this time not as matter of choice but as a «last resort».

\section{REFERENCES}

Bacevieh, Andrew (2002), American Empire. The Realities and Consequences of US. Diplomacy, Cambridge, Harvard University Press.

BIENEFELD, Manfred (2011), «The International policy Framework» in H. Veltmeyer (ed.) The Critical Development Studies Reader: Tools for Change, Halifax, Fernwood Publications / London, Pluto Books.

Biersteker, T. (1992), "The "Triumph" of Neoclassical Economics in the Developing World: Policy Convergence and the Bases of Government in the International Economic Order» in James Rosenau and E. O. Czempiel (eds.), Governance without government: Order and change in World Politics, Cambridge, Cambridge University Press.

Blustein, Paul (2001), The Chastening: Inside the Crisis That Rocked the Global Financial System and Humbled the IMF, New York, Public Affairs. Воот, Max (2002), The Savage Wars of Peace: Small Wars and the Rise of American Power, New York, Basic Books. 
BRANDS, H. W. (1999), «The Idea of the National Interest» in Michael Hogan (ed.), The Ambiguous Legacy: US Foreign Relations in the American Century, New York, Cambridge University Press.

BusH, George and Brent Scowcroft (1998), A World Transformed, New York, Alfred A. Knopf.

CARrothers, Thomas (1991), «The Reagan Years: The 1980s» in Abraham Lowenthal (ed.), Exporting Democracy: The United States and Latin America, Baltimore, Johns Hopkins University Press.

Craig, D. and D. Porter (2006) Development Beyond Neoliberalism? Governance, Poverty Reduction and Political Economy, Abingdon Oxon, Routledge.

COOPER, Robert (2000), «The New Liberal Imperialism» in The Guardian, april 7.

CyPher, J. and Raúl Delgado Wise (2007), «Subordinate Economic Integration Through the Labour-Export Model: A Perspective from Mexico» in Paul Bowles, Henry Veltmeyer et al. (eds.) National Perspectives on Globalization, New York, Palgrave Macmillan.

DAALDER, Ivo and James Lindsay (2003), America Unbound: The Bush Revolution in Foreign Policy, Washington, Brookings Institution Press.

Eichengreen, Barry (1996), Globalizing Capital: A History of the International Monetary System, Princeton, Princeton University Press.

FErguson, Niall (2004), Colossus. The Price of America's Empire, London, Penguin.

GALlagher, John A. and Ronald E. Robinson (1953), «The Imperialism of Free Trade» in Economic History Review, Vol 6 (1): 1-15.

Gowan, Peter (1999), The Global Gamble: Washington's Faustian Bid for World Domination, London, Verso.

HARVEY, David (2003), The New Imperialism, Oxford, Oxford University Press. HEARDEN, Patrick (2002), Architects of Globalism: Building a New World Order during World War II, Fayetteville, University of Arkansas Press.

Hudson, Michael (2003), Super Imperialism. The Origins and Fundamentals of US. World Dominance (2nd ed.), London, Pluto.

KaGAN, Robert and William Kristol (eds.) (2000), Present Dangers: Crisis and Opportunity in American Foreign and Defense Policy, New York, Encounter Publications.

KurTz, Marcus (2004), Free Market Democracy and the Chilean and Mexican Countryside, Cambridge, Cambridge University Press. 
LAFEBER, Waiter (1984), Inevitable Revolutions: The United States in Central America (2nd ed.), New York, Norton.

LundestAD, Geir (1998), «Empire by Invitation: The United States and European Integration, 1945-1997», New York, Oxford University Press.

MaIER, Charles (1987), «The Politics of Productivity: Foundations of American Economic Policy after World War ll» in Charles Maier (ed.), In Search of Stability, Cambridge, Cambridge University Press.

Mann, James (2004), The Rise of the Vulcans: The History of Bush's War Cabinet, New York, Viking Press.

MAnN, Michael (2003), Incoherent Empire, London, Verso.

MCLEAN, David (1995), War, Diplomacy and Informal Empire, London, Tauris.

OCAMPO, José Antonio (1998), «Beyond the Washington Consensus: an ECLAC Perspective» in CEPAL Review, no. 66, December. (2007), «Markets. Social Cohesion and Democracy» in J. A. Ocampo, K. S. Jomo and S. Kahn (eds.), Policy Matters: Economic and Social Policies to Sustain Equitable Development, London, Zed.

PEET Richard (2003), Unholy Trinity: The IMF, World Bank and TWO, London, Zed.

PETRAS, James (2005), «Latin American Strategies: Class-Based Direct Action Versus Populist Electoral Politics» in Science and Society, no. 69.

PETras, James and Henry Veltmeyer (2001), Unmasking Globalization: The New Face of Imperialism, Halifax, Fernwood Publications/ London, Zed. (2003), System in Crisis: The Dynamics of Free Market Capitalism. Halifax, Fernwood Publications/ London, Zed. (eds.) (2004), Las privatizaciones y la desnacionalización en América Latina, Buenos Aires, Prometeo. (2005), Empire with Imperialism, Halifax, Fernwood Publications/ London, Zed.

(2005b), Social Movements and the State: Argentina, Bolivia, Brazil, Ecuador, London, Pluto Press. (2009), What's Left in Latin America, London, Ashgate. (2011), Social Movements in Latin America: Neoliberalism and Popular Responses, New York, Palgrave Macmillan.

PILGER, John (2002), The New Rulers of the World, London, Verso.

RoordA, Erie (1998), The Dictator Next Door: The Good Neighbor Policy and the Trujillo Regime in the Dominican Republic, 1930-1945, Durham, Duke University Press. 
SANDbrook, Richard, Marc Edelman et al. (2007), Social Democracy on the Periphery. Cambridge U. K., Cambridge University Press.

SAXE-FERnÁNDEZ, John and Omar Núñez (2001), «Globalización e imperialismo: La transferencia de excedentes de América Latina» in Saxe-Fernández et al. Globalización, Imperialismo y Clase Social, México, Lumen.

Schumpeter, Joseph (1955), «The Sociology of Imperialism» in J. Schumpeter, Imperialism and Social Classes, Cleveland, World Publishing.

SEll, Susan (2002), «Intellectual Property Rights» in David Held and Anthony McGrew (eds.), Governing Globalization: Power, Authority and Global Governance, Cambridge, Polity.

Smith, Peter (2000), Talons of the Eagle. Dynamics of US Latin American Relations, New York, Oxford University Press.

Soederbert, Susanne (2004), The Politics of the New International Financial Architecture: Reimposing Neoliberal Domination in the Global South, New York, Zed.

VAITnEy, Robert (2001), State and Revolution in Cuba: Mass Mobilization and Political Change, 1920-1940, Chapel Hill, University of North Carolina Press.

Veltmeyer, Henry (2005), «The Dynamics of Land Occupation in Latin America» in Sam Moyo and Paris Yeros (eds.), Reclaiming the Land: The Resurgence of Rural Movements in Africa, Asia, and Latin America, London, Zed.

Veltmeyer, Henry and James Petras (2005), «Foreign Aid, Neoliberalism and Imperialism» in Alfredo Saad-Filho and Deborah Johnston (eds.), Neoliberalism: A Critical Reader, London, Pluto Press.

VREELAND, James (2003), The IMF and Economic Development, Cambridge, Cambridge University Press.

Wallerstein, Immanuel (2003), The Decline of American Power: The US in a Chaotic World, New York, New Press.

WEAVER, Frederick (2000), Latin America in the World Economy. Mercantile Colonialism to Global Capitalism, Boulder, Westview.

World Bank (WB) (2007), Meeting the Challenges of Global Development, Washington, October 12. 
